\title{
Efficacy of a cooled bipolar epicardial radiofrequency ablation probe for creating transmural myocardial lesions
}

\author{
Mark A. Wood, MD, ${ }^{\text {a }}$ Amy L. Ellenbogen, ${ }^{\text {a }}$ Vishesh Pathak, BA, ${ }^{a}$ Kenneth A. Ellenbogen, MD, ${ }^{\text {a }}$ and \\ Vigneshwar Kasarajan, MD $^{\mathrm{b}}$
}

Objective: Creation of transmural myocardial lesions with epicardial surgical devices to treat atrial fibrillation is difficult. A new cooled bipolar radiofrequency ablation probe was used to create transmural myocardial lesions under controlled conditions.

\begin{abstract}
Methods: The Coolrail (AtriCure, Inc, West Chester, Ohio) is a handheld probe with 2 parallel $30-\mathrm{mm}$ long radiofrequency conductors. Conductors are cooled by water irrigation. Lesions were delivered to epicardial surface of isolated bovine myocardium sliced 3- to $8-\mathrm{mm}$ thick, with blood flow beneath tissue at 0 or $0.4 \mathrm{~m} / \mathrm{s}$. Contact pressure between probe and tissue was either $450 \mathrm{~g}$ or $900 \mathrm{~g}$. Tissue temperatures were measured. Tissue was sectioned every $5 \mathrm{~mm}$ along lesion long axis to determine lesion dimensions.
\end{abstract}

Results: For 80 experiments with 450 -g contact pressure, epicardial lesion length was $31.3 \mathrm{~mm}$ (interquartile range, $30.1-32.8 \mathrm{~mm}$ ); endocardial lesion length was $14.1 \mathrm{~mm}$ (interquartile range, $0.0-22.6 \mathrm{~mm}$ ). Average lesion depth was $4.2 \pm 0.74 \mathrm{~mm}$. Temperature at probe interface was $81^{\circ} \mathrm{C} \pm 21^{\circ} \mathrm{C}$; that at blood pool interface was $53^{\circ} \mathrm{C} \pm 12^{\circ} \mathrm{C}$. Lesions were always transmural when tissue thickness was $4.0 \mathrm{~mm}$ or less. Endocardial blood flow did not influence lesion depth. With 900-g contact pressure, increased depth was always transmural at 4.8-mm tissue thickness or less.

Conclusions: This irrigated bipolar radiofrequency probe consistently produced transmural lesions in tissue 4 $\mathrm{mm}$ or thinner under controlled conditions in vitro. Lesion depth was increased by greater pressure on probe and not affected by blood flow. Endocardial lesions were smaller than epicardial dimensions. (J Thorac Cardiovasc Surg 2010;139:453-8)

Minimally invasive surgical approaches to the treatment of atrial fibrillation have been developed as alternatives to the successful but highly invasive surgical maze procedure. ${ }^{1,2}$ These minimally invasive procedures have used a variety of energy sources to produce myocardial lesions, including cryoablation, microwave, laser, and radiofrequency current. ${ }^{3}$ For all energy modalities, the ability to produce controlled, consistent transmural lesions has been a major challenge. Although bipolar radiofrequency clamps can effectively isolate the pulmonary veins through a limited thoracotomy, the treatment of patients with persistent forms of atrial fibrillation requires more extensive left atrial ablation. ${ }^{1,4}$ In the beating heart, handheld unipolar radiofrequency probes rarely produce transmural lesions. ${ }^{3,5}$ Newer bipolar surgical radiofrequency probes show more promise. ${ }^{4}$ Active cooling of the radiofrequency electrode by fluid irrigation greatly increases the electrical current that can be delivered for endocardial ablation by percutaneous radiofrequency catheters. ${ }^{6,7}$ It is hypothesized

\footnotetext{
From the Division of Cardiac Electrophysiology ${ }^{\mathrm{a}}$ and the Department Cardiothoracic Surgery, ${ }^{\mathrm{b}}$ Virginia Commonwealth University Medical Center, Richmond, Va. Disclosures: None.

Received for publication March 23, 2009; revisions received May 18, 2009; accepted for publication June 4, 2009; available ahead of print Sept 14, 2009.

Address for reprints: Mark A. Wood, MD, Box 980053, Virginia Commonwealth University Medical Center, Richmond, VA 23298-0053 (E-mail: mwoodmd@pol.net). $0022-5223 / \$ 36.00$

Copyright (c) 2010 by The American Association for Thoracic Surgery doi:10.1016/j.jtcvs.2009.06.028
}

that active cooling of handheld epicardial radiofrequency ablation electrodes will similarly enhance energy delivery and thus transmural lesion formation. This study examined the ability of a new irrigated bipolar radiofrequency surgical probe to create transmural myocardial lesions under controlled conditions. The influences of electrode contact pressure and simulated endocardial blood flow were also studied.

\section{MATERIALS AND METHODS \\ Radiofrequency Ablation Device}

The Coolrail linear ablation pen (AtriCure, Inc, West Chester, Ohio) is a handheld surgical device for epicardial ablation (Figure 1). The device is intended to create transmural lesions in the body of the atria during surgical procedures for atrial fibrillation. This device is not intended to isolate the pulmonary veins. The working end of the device comprises 2 linear radiofrequency electrodes, each $30 \mathrm{~mm}$ in length, in parallel $5 \mathrm{~mm}$ apart (Figure 1). The electrodes are actively cooled by internal irrigation with room-temperature sterile water $(20 \mathrm{~mL} / \mathrm{min})$ through the head of the device. Radiofrequency current is delivered in bipolar configuration between the 2 linear electrodes (ASU2 generator; AtriCure). With activation of the generator, radiofrequency energy is delivered in a power-controlled mode at $30 \mathrm{~W}$ for 40 seconds (impedance 50 to $250 \Omega$ ). Energy output and impedance were sampled from the generator at $10 \mathrm{~Hz}$ with a personal computer and custom software. The role of the manufacturer in this study was to provide preserved tissue specimens, the radiofrequency generator, probe, and computer. We and the manufacturer performed statistical analyses independently to check for validity.

\section{Tissue Preparations}

Bovine hearts were obtained from a meat processing facility, and sections of left ventricle were cut to dimensions of $40 \mathrm{~mm}$ in length and 30 
$\mathrm{mm}$ in width. The epicardial surface was preserved in each section to receive the radiofrequency delivery. The tissue pieces were sectioned from the endocardial aspect to thicknesses of approximately $4,5,6$, or $7 \mathrm{~mm}$ with a tissue microtome, again leaving the epicardial surface intact. Bovine hearts were used because of their high yield of sections with intact epicardial surfaces.

In addition to the study of preserved bovine tissue, experiments were repeated with live porcine left ventricular myocardium. These experiments were undertaken to identify differences from the use of preserved, nonviable tissue. Viable porcine hearts were harvested at our institution after completion of protocols approved by our institutional animal care and use committee. These hearts were preserved in iced saline solution until manually sectioned to dimensions described previously, preserving the epicardial surface in each sample. Porcine hearts were used for the viable tissue experiments because the pig was the largest animal $(35-45 \mathrm{~kg}$ ) model feasible for viable tissue collection in large numbers.

\section{Experimental Apparatus}

The tissue sections were rested epicardial surface upward on a thin latex membrane $(0.08 \mathrm{~mm})$ in a warmed $\left(38^{\circ} \mathrm{C}\right)$ tissue bath (Figure 1$)$. The bath was filled with heparinized bovine or porcine whole blood, such that the level of the blood reached the underside of the latex membrane but did not rise above the membrane to contact the tissue. This simulated a surgical exposure of the epicardial aspect of the heart with the underlying endocardial blood pool. With a roller pump, blood in the bath was circulated at controlled velocity beneath the latex membrane. The tissue bath rested on a digital scale (2-g resolution). The handle of the epicardial ablation probe was fixed in a pivoting mount (Figure 1). The ablation electrodes were applied to the epicardial surface of the tissue. By sliding a weight sled along the neck of the ablation probe, the exact amount of contact pressure exerted on the tissue by the probe could be adjusted and measured from the digital scale readout. Two fluoro-optic temperature probes $(0.8 \mathrm{~mm}$ in diameter; Luxtron Inc, Santa Clara, Calif) were placed between the epicardial surface of the tissue and the radiofrequency device, and 2 temperature probes were placed between the latex membrane and the "endocardial" aspect of the tissue. Each of the 4 probes was located $5 \mathrm{~mm}$ from the end of the ablation electrodes (Figure 1).

\section{Histologic Examination}

After lesion formation, the epicardial and endocardial lesion dimensions were measured with digital calipers (0.01-mm resolution). The tissue was then cross-sectioned at one end of the epicardial aspect of the lesion and then at 5-mm intervals along the long axis of the lesion to yield 5 or 6 cross sections per experiment, depending on lesion length. For the viable porcine tissue experiments, the tissue was then stained with nitroblue tetrazolium $(0.05 \mathrm{mg} / \mathrm{mL})$ to delineate viable from nonviable tissue. At each cross section, the tissue thickness, lesion depth, and lesion width were measured with the described digital calipers.

\section{Protocols}

For the preserved bovine myocardium, tissue sections were cut to average thicknesses of $4,5,6$, and $7 \mathrm{~mm}$. The radiofrequency probe was positioned with a contact pressure of $450 \mathrm{~g}$ (recommended by manufacturer). Blood flow was directed under the tissue at either 0 or $0.4 \mathrm{~m} / \mathrm{s}$. Radiofrequency energy was delivered for 40 seconds at $30 \mathrm{~W}$ for all lesions. Temperatures at the electrode-tissue and tissue-blood pool interfaces were recorded at 2 seconds before the termination of radiofrequency delivery. Ten experiments were performed for each approximate tissue thickness $(4,5,6$, or $7 \mathrm{~mm})$ and each blood flow velocity $(0$ or $0.4 \mathrm{~m} / \mathrm{s})$ for a total of 80 experiments. Twenty experiments with the preserved bovine myocardium were performed with doubled contact pressure of $900 \mathrm{~g}$, with and without blood flow and with tissue sections cut to thicknesses of approximately 5,6 , or $7 \mathrm{~mm}$ to allow recognition of increased lesion depth.

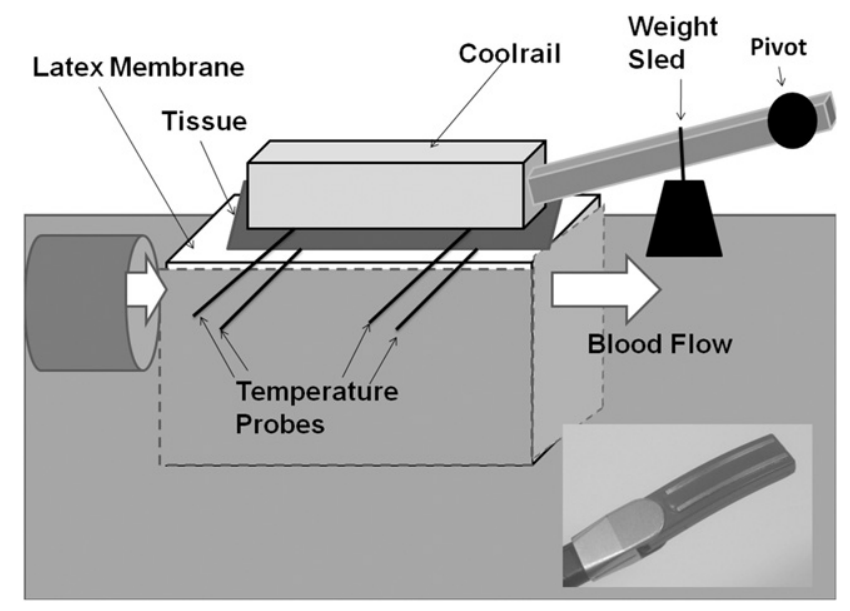

FIGURE 1. Coolrail device (AtriCure, Inc, West Chester, Ohio) and experimental apparatus. Myocardial tissue rests on 0.08-mm thick latex membrane stretched between 2 supports. Blood flow is directed under length of membrane at controlled velocity. Ablation probe handle is supported in pivot mechanism proximally. Tissue bath rests on digital scale. By adjusting sliding weight, contact pressure exerted by head of device is controlled. Four optic temperature probes record interface temperatures between tissue and ablation probe and between tissue and latex membrane. Insert, Close up of head of bipolar radiofrequency ablation device with 2 parallel electrodes.

For the viable porcine tissue, 10 experiments each were performed for all permutations of the following variables: tissue thickness approximately 4 or $5 \mathrm{~mm}$, contact pressure of $450 \mathrm{~g}$, and blood flow at 0 or $0.4 \mathrm{~m} / \mathrm{s}$, for a total of 40 experiments.

\section{Statistics}

Values are presented as mean $\pm \mathrm{SD}$ or median with interquartile range. The $t$ test, analysis of variance, and Mann-Whitney $U$ test were used as appropriate for comparisons among independent groups. Logistic regression was used for factors associated with transmural lesion formation.

\section{RESULTS}

\section{Preserved Bovine Myocardium at 450-g Pressure}

For the preserved bovine myocardium at 450 -g pressure, the range of tissue thicknesses measured on cross sections of the lesions was 2.98 to $9.64 \mathrm{~mm}$ (average, $4.9 \pm$ $1.3 \mathrm{~mm})$. The average tissue thicknesses were similar for each of the 6 cross sections $(P=.16)$. The endocardial lesion length and width were significantly smaller than the epicardial dimensions (both $P<.001$; Figure 2 and Table 1). For the preserved bovine myocardium, lesion depth was always transmural for tissue thicknesses $4.0 \mathrm{~mm}$ or less (Figure 3). At tissue thicknesses of 4.1 to $4.5 \mathrm{~mm}, 80 \%$ of cross sections were transmural; at thicknesses of 4.6 to $5.0 \mathrm{~mm}, 60 \%$ of lesions were transmural; and at 5.1 to $5.5 \mathrm{~mm}$, only $21 \%$ of lesions were transmural (Figure 4). Temperatures measured at the interface between ablation electrode and tissue $\left(81.8^{\circ} \mathrm{C} \pm\right.$ $19.7^{\circ} \mathrm{C}$ ) were significantly greater than temperatures at the blood pool-tissue interface $\left(51.8^{\circ} \mathrm{C} \pm 10.8^{\circ} \mathrm{C}, P<.001\right.$; Table 1). The full $30-\mathrm{W}$ radiofrequency power was delivered in these and all subsequently described experiments. 

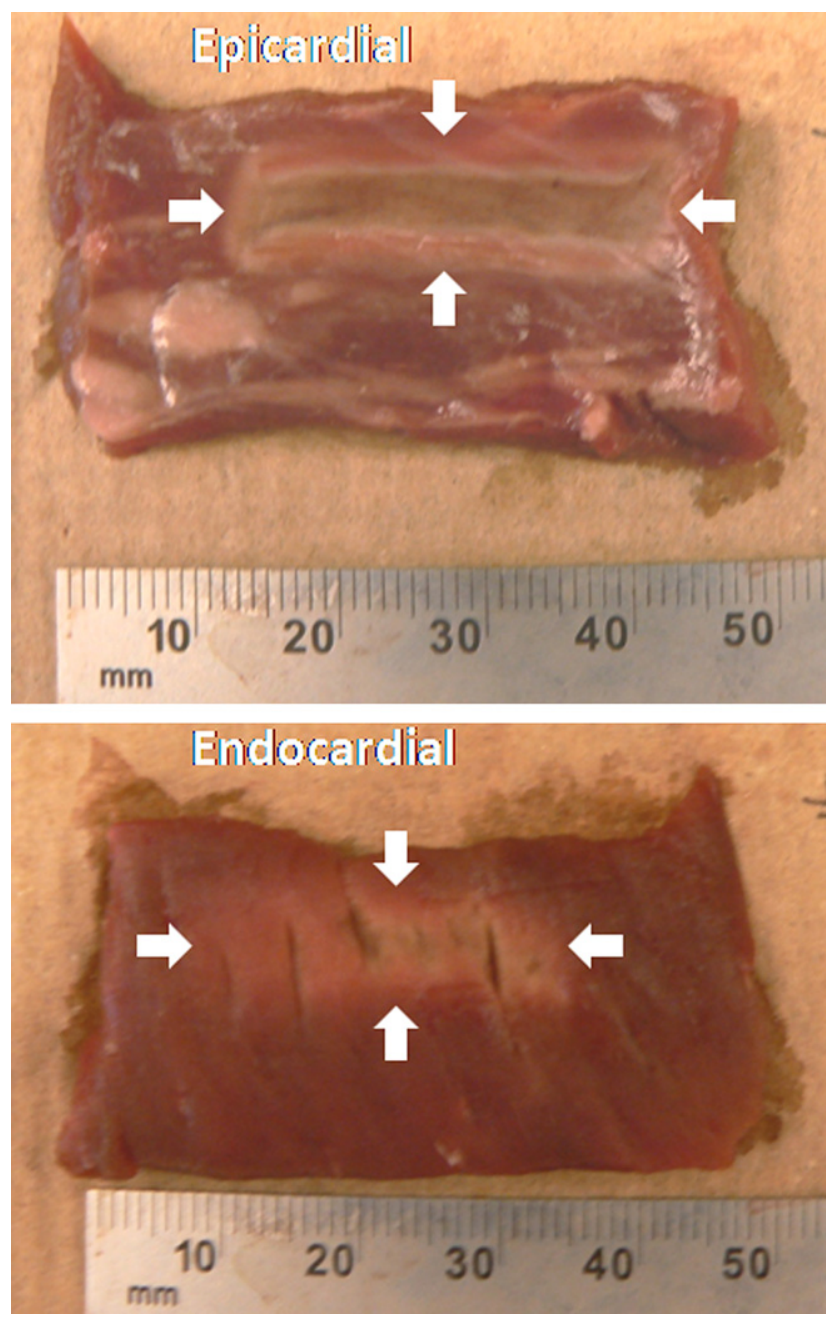

FIGURE 2. Epicardial and endocardial lesions from same experiment with preserved tissue, average tissue thickness approximately $5 \mathrm{~mm}$, blood flow at $0.4 \mathrm{~m} / \mathrm{s}$, and $450-\mathrm{g}$ contact pressure. Epicardial lesion length is $31.3 \mathrm{~mm}$, and width is $9.2 \mathrm{~mm}$. Endocardial lesion length is $25.5 \mathrm{~mm}$, and width is $8.1 \mathrm{~mm}$.

\section{Effects of Simulated Endocardial Blood flow}

The presence of simulated endocardial blood flow did not affect endocardial or epicardial lesion dimensions relative to the absence of endocardial blood flow (all $P>.05$; Table 2). Average lesion depth was not affected by simulated endocardial blood flow (lesion depth $4.5 \pm 0.8 \mathrm{~mm}$ with flow vs $4.5 \pm 0.7 \mathrm{~mm}$ without flow, $P=.66$ ), nor was the tissue thickness always associated with transmural lesions $(\leq 4.0$ $\mathrm{mm}$ with or without blood flow). Average epicardial and endocardial temperatures were not affected by the presence of blood flow (all $P>.05$ ).

\section{Preserved Tissue at 900-g Pressure}

Ten experiments each were performed with and without flow on tissues with average section thickness of $6.0 \pm 1.2$ $\mathrm{mm}$ and contact pressure of $895 \pm 15 \mathrm{~g}$. The average lesion depth was $5.1 \pm 0.4 \mathrm{~mm}$ (maximal depth, $5.88 \mathrm{~mm}$ ). The lesion was always transmural for tissue thicknesses less than $4.8 \mathrm{~mm}$ (Figure 3). Surface lesion dimensions and lesion depth were not influenced by simulated endocardial blood flow (all $P>.05$; Table 2). Compared with preserved tissue with $450-\mathrm{g}$ contact pressure in tissue sections of the same thickness as $900-\mathrm{g}$ pressure experiments $(4.0-8.7 \mathrm{~mm})$, the greater pressure resulted in a greater lesion depth $(5.1 \pm$ $0.4 \mathrm{~mm}$ vs $4.5 \pm 0.5 \mathrm{~mm}, P<.001)$ and higher epicardial $\left(89.9^{\circ} \mathrm{C} \pm 19.4^{\circ} \mathrm{C}\right.$ vs $\left.81.8^{\circ} \mathrm{C} \pm 19.7^{\circ} \mathrm{C}, P<.001\right)$ and endocardial $\left(58.4^{\circ} \mathrm{C} \pm 11.7^{\circ} \mathrm{C}\right.$ vs $\left.51.8^{\circ} \mathrm{C} \pm 10.8^{\circ} \mathrm{C}, P<.001\right)$ temperatures (Table 2). Cross-sectional lesion width was not altered by increased contact pressure. Epicardial and endocardial lesion dimensions were not different from those of preserved tissue with $450 \mathrm{~g}$ contact pressure (all $P \geq .07$ ).

\section{Viable Porcine Tissue}

Twenty experiments each were performed on viable porcine myocardium with and without simulated blood flow and with contact pressure of $450 \mathrm{~g}$. The average tissue section thickness was $5.4 \pm 1.5 \mathrm{~mm}$ (range, $2.0-9.4 \mathrm{~mm}$ ). Lesion formation was always transmural for tissue less than 4.4 $\mathrm{mm}$ in thickness. The average lesion depth $(4.7 \pm 0.7$ $\mathrm{mm})$ was significantly greater than for the preserved tissue $(4.6 \pm 0.7 \mathrm{~mm}, P<.001)$ when analyzing tissue sections of thicknesses common to both experimental groups $(>4.0$ $\mathrm{mm}$ and $\leq 9.4 \mathrm{~mm})$. Epicardial and endocardial lesion

TABLE 1. Parameters for preserved and viable tissues

\begin{tabular}{|c|c|c|c|}
\hline & \multicolumn{2}{|c|}{ Preserved } & \multirow[b]{2}{*}{ Viable, pressure $450 \mathrm{~g}$} \\
\hline & Pressure $450 \mathrm{~g}$ & Pressure $900 \mathrm{~g}$ & \\
\hline Epicardial length (mm) & $31.3(30.1-32.8)$ & $32.0(29.5-33.6)$ & $30.7(30.1-31.6)$ \\
\hline Epicardial width (mm) & $10.3(9.7-11.0)$ & $10.8(10.3-11.4)$ & $10.3(9.3-10.8)$ \\
\hline Endocardial length (mm) & $14.1(0.0-22.6)^{*}$ & $5.25(0.0-19.23 *$ & $11.3(0.0-19.5)^{*}$ \\
\hline Endocardial width (mm) & $7.7(0.0-9.8)^{*}$ & $2.9(0.0-19.23)^{*}$ & $7.3(0.0-9.6)^{*}$ \\
\hline Lesion depth (mm, mean $\pm \mathrm{SD}) \dagger$ & $4.6 \pm 0.5$ & $4.7 \pm 0.5 \ddagger$ & $5.1 \pm 0.4 \ddagger$ \\
\hline Epicardial temperature $\left({ }^{\circ} \mathrm{C}\right.$, mean $\left.\pm \mathrm{SD}\right)$ & $81.8 \pm 19.7$ & $89.9 \pm 19.4$ & $80.8 \pm 18.7$ \\
\hline Endocardial temperature $\left({ }^{\circ} \mathrm{C}\right.$, mean $\left.\pm \mathrm{SD}\right)$ & $51.8 \pm 10.8^{*}$ & $58.4 \pm 11.7 *$ & $54.3 \pm 10.6^{*}$ \\
\hline
\end{tabular}

Data are median with interquartile range except as marked. Lower quartile values of 0.0 result from lesions that are not transmural at any point in the tissue. $* P<.01$ versus epicardial values. $\dagger$ For tissue sections with thicknesses greater than 4.0 and less than $8.7 \mathrm{~mm}$ that are common to all 3 groups. $\ddagger P<.001$ versus preserved 450 -g group. 

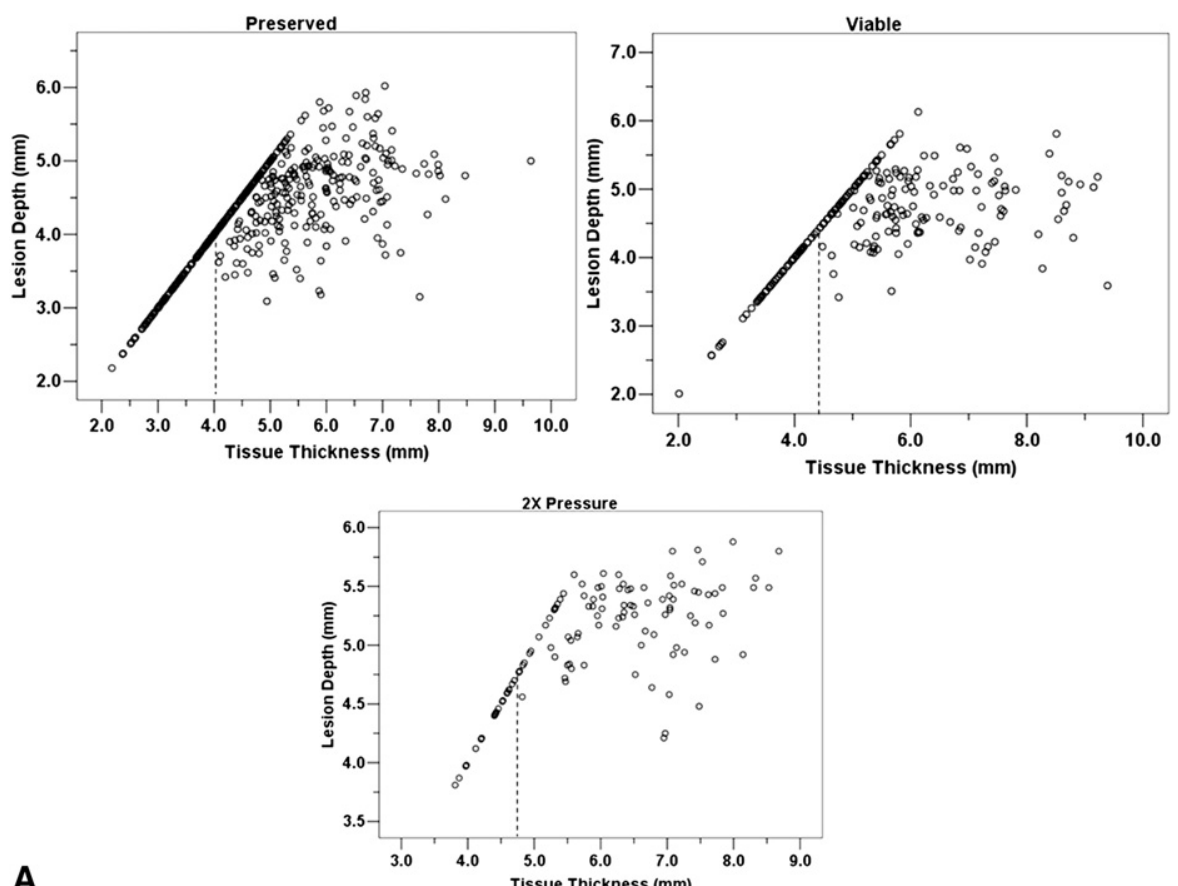

A

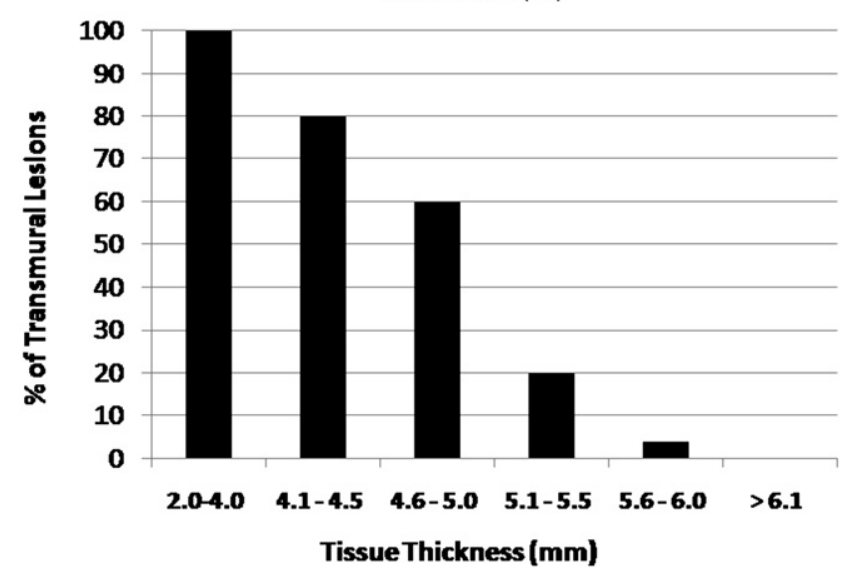

FIGURE 3. A, Tissue thickness versus lesion thickness for 3 experimental groups. Points deviating from line of unity represent nontransmural lesions. Maximal tissue thickness without producing nontransmural lesion is indicated by dotted vertical line in each graph. B, Percentage of lesions that were transmural on cross section by tissue section thickness at level of section. Data are for preserved tissue with $450-\mathrm{g}$ contact pressure. Four hundred twenty-eight tissue sections from 80 experiments are represented.

dimensions were not different in the presence and the absence of simulated endocardial blood flow (Table 2).

Regression analysis was performed on all experiments combined to identify variables associated with transmural lesion formation. Only tissue sections with thicknesses common to all 3 groups $(>4.0$ and $\leq 8.7 \mathrm{~mm})$ were included in the data set analyzed to control for differences in tissue section thicknesses among groups. For a model including tissue type (preserved or viable), blood flow velocity, contact pressure, and epicardial and endocardial temperatures, only endocardial temperature $(P=.02)$ and contact pressure $(P<$ $.001)$ were significantly associated with lesion depth $(r=$
$0.40, P<.001)$. The average lesion depths for these 3 groups in this analysis are shown in Table 1.

\section{DISCUSSION}

The major findings of this study are that for this bipolar cooled epicardial ablation probe under controlled conditions (1) transmural lesion thickness is always seen for tissue thicknesses less than $4.0 \mathrm{~mm}$, (2) transmural lesion depth is increased by approximately $0.7 \mathrm{~mm}$ with increased contact pressure, (3) simulated endocardial blood flow does not alter lesion dimensions, and (4) endocardial lesion dimensions are significantly smaller than epicardial 
TABLE 2. Lesion data for preserved and viable tissues

\begin{tabular}{|c|c|c|c|}
\hline & \multicolumn{2}{|c|}{ Preserved } & \multirow{2}{*}{$\begin{array}{c}\text { Viable, } \\
\text { pressure } 450 \mathrm{~g}\end{array}$} \\
\hline & Pressure 450 g & Pressure $900 \mathrm{~g}$ & \\
\hline \multirow{2}{*}{\multicolumn{4}{|c|}{$\begin{array}{l}\text { Epicardial lesion } \\
\text { length }(\mathrm{mm})\end{array}$}} \\
\hline & & & \\
\hline Flow $0 \mathrm{~m} / \mathrm{s}$ & $31.1(30.2-32.6)$ & $31.6(28.5-33.7)$ & $30.7(30.1-31.3)$ \\
\hline Flow $0.4 \mathrm{~m} / \mathrm{s}$ & $31.4(30.1-32.9)$ & $32.6(30.4-33.8)$ & $30.9(29.0-32.6)$ \\
\hline \multicolumn{4}{|c|}{$\begin{array}{c}\text { Endocardial lesion } \\
\text { length }(\mathrm{mm})\end{array}$} \\
\hline Flow $0 \mathrm{~m} / \mathrm{s}$ & $16.9(0.0-24.1)$ & $0.0(0.0,23.1)$ & $16.1(0.0-22.2)$ \\
\hline Flow $0.4 \mathrm{~m} / \mathrm{s}$ & $12.9(0.0-19.3)$ & $11.6(0.0-15.0)$ & $9.2(0.0-17.9)$ \\
\hline \multicolumn{4}{|l|}{$\begin{array}{l}\text { Epicardial lesion } \\
\text { width (mm) }\end{array}$} \\
\hline Flow $0 \mathrm{~m} / \mathrm{s}$ & $10.3(9.7-11.0)$ & $10.8(9.7-11.4)$ & $10.0(9.3-10.6)$ \\
\hline Flow $0.4 \mathrm{~m} / \mathrm{s}$ & $10.3(9.5-11.0)$ & $10.8(10.5-11.4)$ & $10.5(9.5-10.9)$ \\
\hline \multicolumn{4}{|c|}{$\begin{array}{c}\text { Endocardial lesion } \\
\text { width }(\mathrm{mm})\end{array}$} \\
\hline Flow $0 \mathrm{~m} / \mathrm{s}$ & $8.0(0.0-9.9)$ & $0.0(0.0-9.6)$ & $7.8(0.0-9.2)$ \\
\hline Flow $0.4 \mathrm{~m} / \mathrm{s}$ & $7.2(0.0-9.6)$ & $6.25(0.0-10.1)$ & $6.4(0.0-10.2)$ \\
\hline
\end{tabular}

Data are median with interquartile range. Lower quartile values of 0.0 result from that are not transmural at any point in the tissue.

dimensions under all conditions. In addition, the depth of radiofrequency lesions created in preserved tissue $(4.6 \pm 0.5$ $\mathrm{mm}$ ) closely approximates lesion depths created in viable tissue $(4.7 \pm 0.5 \mathrm{~mm})$. The estimate of 4 -mm tissue thickness always producing transmural lesion formation is conservative, because with viable tissue the lesions were always transmural to $4.4 \mathrm{~mm}$.

The ability to create transmural atrial lesions without atriotomy has been a limiting factor in the development of the minimally invasive emulation of the surgical maze procedure. Many energy sources have been adapted to epicardial application, including cryothermal energy, laser, microwave, ultrasound, and radiofrequency energy. ${ }^{4}$ Of these, radiofrequency energy has shown the most promise but is still in evolution. Unipolar radiofrequency energy delivery on the epicardium rarely produces transmural linear lesions, even in tissue less than $2 \mathrm{~mm}$ in thickness. ${ }^{5}$ Devices for bipolar radiofrequency delivery have proven more efficacious. Bipolar clamps appear effective for pulmonary vein isolation, creating transmural lesions in tissue as thick as $5 \mathrm{~mm}$, but are unable to produce linear atrial lesions without atriotomy. ${ }^{4,6}$ To overcome the limitations of unipolar probes to produce linear lesions, irrigated handheld radiofrequency ablation probes such as that used in this study have been developed. By irrigation of the electrodes, excessive interface temperatures with the tissue and impedance rises are avoided. ${ }^{7,8}$ This enables greater radiofrequency current delivery and tissue heating. This principle is evident by the average electrode-tissue interface temperature less than $90^{\circ} \mathrm{C}$ shown in this study. Our study demonstrates the ability of this irrigated bipolar ablation system to produce consistent lesions as deep as $4.0 \mathrm{~mm}$ under controlled conditions.
This value is significant, because the average left atrial wall thickness between the upper pulmonary veins is been reported as $2.3 \pm 0.9 \mathrm{~mm}$ in patients with atrial fibrillation, and the atrial thickness between the left pulmonary veins and appendage is $2.8 \pm 1.1 \mathrm{~mm} .{ }^{9,10}$ Lesion depth is increased to $5.1 \mathrm{~mm}$ consistently with 2 -fold contact pressure on the probe. This enhanced lesion depth may result from greater electrical coupling of the probe with the tissue or from tissue compression caused by the greater pressure. The additional lesion depth may be necessary for ablation of the mitral isthmus, because the myocardial thickness here is $3.8 \pm 0.9 \mathrm{~mm}$ (range, $2.2-5.5 \mathrm{~mm})^{9}$

\section{Clinical Implications}

This device appears capable of consistently producing transmural myocardial lesions $4.0 \mathrm{~mm}$ in depth. The depth may be increased to $5 \mathrm{~mm}$ if sufficiently greater contact force can be applied to the probe. On the basis of these studies, endocardial blood flow would not be expected to influence lesion formation greatly. The endocardial lesion length is significantly shorter than that visible on the epicardium. It appears necessary to apply overlapping lesions to create long transmural lesions. Because lesion transmurality becomes less predictable for tissue depths more than $4 \mathrm{~mm}$, preoperative or intraoperative atrial imaging (computed tomography, magnetic resonance imaging, or echocardiography) may be useful to identify potentially problematic target areas for epicardial ablation.

\section{Limitations}

This study was performed in isolated tissue under controlled conditions. Epicardial ablation in the beating heart is more difficult than in isolated tissue. ${ }^{10}$ The generation of sufficient contact pressure is difficult to assess in clinical cases. Because of variable patient anatomy and the constraints of the surgical access, the generation of contact forces of 450 to $900 \mathrm{~g}$ may not be possible for all energy deliveries. The lesions were not assessed for electrical conduction block. Only acute lesion sizes were assessed. The long-term dimensions of lesions may differ. Performance of the device over endocardial fat tissue was not tested. The performance of this device near the coronary arteries (such as the mitral isthmus) is also not known.

\section{References}

1. Edgerton JR, Edgerton ZJ, Weaver T, Reed K, Prince S, Herbert MA, et al. Minimally invasive pulmonary vein isolation and partial autonomic denervation for surgical treatment of atrial fibrillation. Ann Thorac Surg. 2008;86:35-9.

2. Wudel JH, Chaudhuri P, Hiller JJ. Video-assisted epicardial ablation and left atrial appendage exclusion for atrial fibrillation: extended follow-up. Ann Thorac Surg 2008;85:34-8.

3. Lall SC, Damiano RJ Jr. Surgical ablation for atrial fibrillation. J Interv Card Electrophysiol. 2007;20:73-82.

4. Melby SJ, Gaynor SL, Lubahn JG, Lee AM, Rahgozar P, Caruthers SD, et al Efficacy and safety of right and left atrial ablations on the beating heart with irrigated bipolar radiofrequency energy: a long-term animal study. $J$ Thorac Cardiovasc Surg. 2006;132:853-60. 
5. Santiago T, Melo J, Gouveia RH, Neves J, Abecasis M, Adragao P, et al. Epicardial radiofrequency applications: in vitro and in vivo studies on human atrial myocardium. Eur J Cardiothorac Surg. 2003;24:481-6.

6. Prasand SM, Maniar HS, Diodata MD, Schuessler RB, Damiano RJ Jr. Physiologic consequences of bipolar radiofrequency energy on the atria and pulmonary veins: a chronic animal study. Ann Thorac Surg. 2003;76:836-42.

7. Nakagawa H, Yamanashi WS, Pitha JV, Arruda M, Wang X, Ohtomo K, et al. Comparison of in vitro tissue temperature profile and lesion geometry for radiofrequency ablation with a saline-irrigated electrode versus temperature control in a canine thigh muscle preparation. Circulation. 1995;91:2264-73.

8. Demazumder D, Mirotznik MS, Schwartzman D. Biophysics of radiofrequency ablation using an irrigated electrode. J Interv Card Electrophysiol. 2001;5:377-89.
9. Platonov PG, Ivanov V, Ho SY, Mitrofanova L. Left atrial posterior wall thickness in patients with and without atrial fibrillation: data from 298 consecutive autopsies. J Cardiovasc Electrophysiol. 2008;19:689-92.

10. Cabrera JA, Ho SY, Climent V, Sánchez-Quintana D. The architecture of the left atrial lateral wall: a particular anatomic region with implications for ablation of atrial fibrillation. Eur Heart J. 2008;29:356-62.

11. Wittkampf FH, van Oosterhout MF, Loh P, Derksen R, Vonken EJ, Slootweg PJ, et al. Where to draw the mitral isthmus line in catheter ablation of atrial fibrillation: histological analysis. Eur Heart J. 2005;26:689-95.

12. Bugge E, Nicholson IA, Thomas SP. Comparison of bipolar and unipolar radiofrequency ablation in an in vivo experimental model. Eur J Cardiothorac Surg. 2005;28:76-82 